University of Michigan Law School

University of Michigan Law School Scholarship Repository

Articles

Faculty Scholarship

1921

\title{
Adversary Parties - Same Person as Both Plaintiff and Defendant
}

Edson R. Sunderland

University of Michigan Law School

Available at: https://repository.law.umich.edu/articles/1104

Follow this and additional works at: https://repository.law.umich.edu/articles

Part of the Civil Procedure Commons

\section{Recommended Citation}

Sunderland, Edson R. "Adversary Parties-Same Person as Both Plaintiff and Defendant." Mich. L. Rev. 20 (1921): 90-3.

This Response or Comment is brought to you for free and open access by the Faculty Scholarship at University of Michigan Law School Scholarship Repository. It has been accepted for inclusion in Articles by an authorized administrator of University of Michigan Law School Scholarship Repository. For more information, please contact mlaw.repository@umich.edu. 
Adversary Parties-Same, Person as Both Plaintmf and Defendant. - Under the regulations promulgated by the Railroad Administration in IgI8, all actions for injury to persons or property growing out of the possession or control of any railroad or system of transportation by the Director General of Railroads were required to be brought against the Director General. ORDER No. 50. Some courts refused to follow this order on the ground that it was contrary to the statute creating federal control. Lavalle v. Northern Pacific Railway Company, (1919), I43 Minn. 74; Franke v. Chi. cago \& N.W. Ry. Co., (I919), 170 Wis. 7I.

But Order No. 50 has been generally observed, and actions arising under federal control have usually been brought against the Director General. He was declared to be the agent of the United States through which it exercised "no divided but a complete possession and control" of all railroads for all purposes. Northern Pac. Ry. Co. v. North Dakota, (Igr8), 250 U. S. 135, I48.

Under this situation a float belonging to the Central Railroad of New Jersey was rammed by a steam tug owned by the New York Central Railroad, and the Globe and Rutgers Fire Insurance Company, as insurer of the float, paid the loss and brought suit against the wrongdoer under its right of subrogation. According to Order No. 50, the wrongdoer was the Director General of Railroads, who was operating the New York Central Railroad and its steam tug. But since the insurer, as subrogee, stood in the shoes of the insured, and the insured, under federal control, was the Director General of Railroads, the action presented in controversy between the Director General of Railroads as operator of the Central Railroad of New Jersey and the Director General of Railroads as operator of the New York Central Railroad. But no one can sue himself, even in another capacity, so that the United States Circuit Court of Appeals for the Second Circuit held that the insured was absolutely without a remedy. Globe and Rutgers Fire Insurance Co. v. Hines, (1921), 273 Fed. Rep. 774

The court here invokes a rule which has often been quoted in both legal

2 Williamson v. Osenton, 232 U. S. 6I9; Young v. Pollak, 85 Ala. 439, 5 So. 279; McConnell v. Kelley, ${ }^{3} 8$ Mass. 372.

24 It is not claimed, of course, that the power of a wife to establish a separate dumicile at all times is authoritatively established. See Suter v. Suter, 72 Miss. 345, Ió So. 673; Hood v. Hood, II Allen I96. The point is not even arguable until the wife becomes emancipated from the shackles placed on her by the common law. But there is a decision or two where, consciously or unconsciously, the court did go to the full extent of the position here suggested, and numerous dicta having the same tendency. See Smith v. Smith, 4 Mackey (D. C.) 255; Thompson v. Love, 42 Oh. St. 6r, 80: Colvin v. Reed, 55 Pa. St. 375; Prater v. Prater, 87 Tenn. 78, 9 S. W. $36 \mathrm{r}$; Dutcher v. Dutcher, 39 Wis. 651, 659; Buchholz v. Buchholz, 63 Wash. 213, 115 Pac. 88. 
and equitable actions, but it has usually been deemed sufficient to state it as a sort of axiomatic formula, without attempting to give any reason for it. Thus, in Bryan v. Kales, (1892), 3 Ariz. 423, the court said that the presence of adversary parties was so fundamental that if it appeared that the plaintiff was suing personally in a suit against himself as administrator, any judgment entered would be "utterly void." Similar views seem to have been entertained in Barber v. Barber, (ISII), 32 R. I. 266, where a tax collector sued himself as town treasurer for services. In Grahame v. Harris, (I833), 5 Gill \& J. (Md.) 488 , on the contrary, the court said that, although a man cannot properly bring an action against himself, and therefore the same party cannot regularly be placed on both sides of the case, this objection is a technical one. The rule is stated in DicEY on Pariss ro Acrions (rule 5) that "The same person cannot be both plaintiff and defendant," and he says that this rule "scarcely requires explanation, and results immediately from the fact that it is impossible for a man himself to infringe upon his own rights." But in Connell v. Woodard, (I84I), 5 How. (Miss.) 665, 670, the court seemed less impressed with the inherent impossibility of such an action, for it said the rule was confined in its operation to natural ptrsons, which of course would destroy any claim it might have for being considered a fundamental concept of the law. Nor is the law entirely consistent in this respect when its asserts the identity of a party with himself in another capacity, when it seeks to defeat an action for want of adversary parties, and at the same time asserts want of identity where a person is joined with himself in another capacity when it seeks to defeat an action on the ground of misjoinder of causes of action. Grahame v. Harris, supra; I ENCY. PI. $\& \operatorname{Pr}$. I78, Tit. Actions. In the same way, the law finds no difficulty in discovering a total lack of identity between a party in one capacity and the same party in another capacity when considering the effect of a judgment. As said in a recent case, Chandler v. White Oak Creek Lumber Co., (I914), I3I Tenn. 47, 50:

"The reason that a judgment against a party suing as an individual is not an estoppel in a subsequent action in which he appears in another capacity or character is that in the latter case he is in contemplation of law a distinct person and a stranger to the prior proceedings and judgment. Rathbone v. Hooney, 58 N. Y. 463 ; Jennings v. Jones, 2 Redf. Sur. 95."

When we turn to equitable suits, the courts are found to be less inclined to consider this objection as insuperable. To be sure, the same broad statement of the rule as an axiomatic proposition is often met with. Thus, in 64 Solicirors' Journal, (March, 1920), $3^{18}$, it is said:

"In the Annual Practice, under Ord. 16, rule I, it is stated, 'The same person cannot be both a plaintiff and a defendant in the same action, or an applicant and a respondent to the same summons.' This is treated as, what most people would consider it, a self-evident proposition-at all events, no authority is cited for it. It is, however, 
not uncommon to come across practitioners who suppose that the same person can be a plaintiff in one character and a defendant in another character in the same action."

A note in 5 MASSAChUSETTS LAW QUARTERIY, 467, (Aug. 1920), quoting the above statement, cites a number of Massachusetts cases where the same rule was stated, but it also mentions others where the rule was in fact ignored without comment from court or parties. Thus, in Welch v. Blanchard, (IgII), 208 Mass. 523, each plaintiff is named three times as defendant on account of different interests in the trust fund.

The theory of parties in equity would seem to make it a matter of minor concern whether a party is present in different capacities on the same side or on different sides of the suit. Thus, in Goss v. Suckling, (IgrI), 30 N. Z. L. R. 543, 545, the court said: "It is irregular, as it is unnecessary, in an equity suit as at common law, to make the same person both plaintiff and defendant." So, in 2 TARDY oN RECEIVERS, 2045, the author says: "Although it is not good practice for a person in his representative capacity to sue himself in his individual capacity, as where a receiver of a corporation sues the directors, one of whom is himself, the bill is not demurrable on that ground alone." In support of this he cites Murphy v. Penniman, (I907), I05 Md. 452, where it is shown that, while prior Maryland cases had condemned the practice of a party being on both sides of the case, yet the practice had to some extent prevailed, and that in a court of equity, where the rights of parties can be considered without much regard to the side on which they appear, "the rule is not of such importance as to require the court in all cases to dismiss the bill or sustain a demurrer to it because such practice has been followed." Again, it has been pointed out that in partition suits, under modern statutes, it is immaterial that the groups of persons making up the parties plaintiff and the parties defendant contain a common member. Blaisdell v. Pray, (1878), 68 Me. 269; Senter v. De Bernal, (1869), 38 Cal. 637.

The case under discussion, against the Director General of Railroads, was one in which there was but a single party on each side, and therefore it was one where the situation did not overtax the capacity of a common law judgment. It was also an actual adversary proceeding, for the insurance company, having paid up its loss, was entirely divorced from any community of interest with the Director General. In every respect there was complete antagonism. There was, therefore, no chance of a collusive suit. If this action could not be maintained the insurance company was without a remedy. Should the court, therefore, in view of the somewhat technical character of the objection made, have looked to the substantial nature of the controversy, as common law courts have often done, for example, in actions by use-plaintiffs, and have allowed the action to proceed?

If, under the federal control act, the interests of the New York Central Railroad and of the Central Railroad of New Jersey were really antagonistic in the matter of the injury to the float, it would seem excessively technical to deny the only remedy possible merely because, of the general rule 
adverted to. But it appears that their interests were not antagonistic. Under the statute, 40 U. S. STAT. AT LARGE, Ch. 25, Sec. I2, all moneys received by the railroads during federal control became the property of the United States, and all operating disbursements, such as damages to be paid for injuries to property, were payable out of such moneys. Hence, when the insurance company paid the loss on the float the money went to the United States, and if the company were to be reimbursed as subrogee on its claim against the New York Central Railroad, the reimbursement would have to come out of money belonging to the United States. The United States, therefore, would in substance be required to pay back to the insurance company, by way of damages, the money which it had received from the insurance company by way of indemnity. The question is, therefore, much more than one of adversary parties. It raises the very substantial point as to whether the insurance company was subrogated to any rights against the insured, because of the latter's fault in connection with the loss. On this point the law is clear. If the property is damaged by the tortious act of the insured or its agents or servants, the insurer, if liable under its contract, has no right of subrogation. Phoenix Ins. Co. v. Erie Transportation Co., (I885), II7 U. S. 312. In Simpson v. Thompson, (1877), 3 App. Cas. 279, it was held by the House of Lords that where two ships, the property of the same owner, collide, and the underwriters pay the loss, they have no right of action against the owner of the ship that did the mischief, as he himself had no right, inasmuch as, being the owner of both vessels, any right he had must be a right of action against himself, which is an absurdity and a thing unknown to the law. To the same effect, see Globe Ins. Co. v. Sherlock, (1874), 25 Ohio St. 50, 68.

In the case under review, therefore, the United States Circuit Court of Appeals appears to have come to the only possible decision, and the weakness in the plaintiff's case was not due to a technical rule as to parties but to the fact that the federal statute, by consolidating all the railroads under the unified operation and control of the United States, subjected all insurers of railroad property to the additional burden of being deprived of any recourse through subrogation for injuries caused by the tortious operation of any other railroad property. Congress might have expressly saved such right of recourse by authorizing actions by insurers in all cases where such right of action would have existed prior to federal control, but it did not do so. The plaintiff may, therefore, properly consider the loss of its right of subrogation one of the burdens chargeable to the war.

E. R. S. 